JURNAL PENDIDIKAN, p-ISSN 2715-095X, e-ISSN 2686-5041

Volume 29, No.2, Juli 2020 (177-186)

Online: http://journal.univetbantara.ac.id/index.php/jp

\title{
Model Pembelajaran Kooperatif Tipe Think Pair Share Sebagai Upaya Meningkatkan Prestasi Belajar PKn Siswa Kelas IXC Semester 1 SMP Negeri 2 Sukoharjo Tahun Pelajaran 2018/ 2019
}

\author{
Sri Hartatiningsih
}

SMP Negeri 2 Sukoharjo, Email: dra.srihartatiningsih@gmail.com

\begin{abstract}
Abstrak: Penelitian ini bertujuan untuk meningkatkan prestasi belajar PKn siswa melalui model pembelajaran kooperatif tipe TPS pada siswa kelas IXC SMP Negeri 2 Sukoharjo semester 1 tahun pelajaran 2018/2019. Penelitian ini adalah Penelitian Tindakan Kelas yang dilakukan di kelas IXC SMP Negeri 2 Sukoharjo semester 1 tahun pelajaran 2018/2019 yang berjumah 32 siswa. Teknik pengumpulan data yang digunakan adalah tes, observasi, dan dokumentasi. Tahap-tahap analisis data dalam penelitian ini adalah pengumpulan data, reduksi data, penyajian data, dan penarikan kesimpulan. Indikator keberhasilan adalah nilai rata-rata tes siswa sekurang-kurangnya 80,0 dan banyak siswa dengan nilai di atas kriteria ketuntasan minimal yaitu 75,0 mencapai $\geq 90 \%$. Berdasarkan penelitian yang telah dilakukan, dapat disimpulkan bahwa penerapan model pembelajaran kooperatif tipe TPS dapat meningkatkan prestasi belajar PKn materi Menampilkan Partisipasi dalam Pembelaan Negara siswa kelas IXC SMP Negeri 2 Sukoharjo. Sebelum tindakan/prasiklus, prestasi belajar siswa yang mencapai KKM 18 siswa atau 56,25\%, pada siklus I, 25 siswa atau 78,12\% dan pada siklus II, 30 siswa atau $93,75 \%$. Nilai rata-rata kelas sebelum tindakan/prasiklus sebesar 74,56 setelah tindakan siklus I sebesar 77,81 dan setelah tindakan siklus II sebesar 82,88.
\end{abstract}

Kata-kata Kunci:Model pembelajaran kooperatif tipe TPS, prestasi belajarPKn.

\section{Model of Cooperative Learning Type Think Pair Share As An Effort to Improve Learning Achievement of Civic Education On The Students of Class IX C Semester 1 SMP Negeri 2 Sukoharjo year Academic 2018/2019}

\author{
Sri Hartatiningsih \\ SMP Negeri 2 Sukoharjo,Email: dra.srihartatiningsih@gmail.com
}

\begin{abstract}
This study aims to improve the learning achievementof the civic educationby learning model type TPS in students of class IXC SMP Negeri 2 Sukoharjo first semester academic year 2018/2019. This research is a Classroom Action Research conducted in class IXC SMP Negeri 2 Sukoharjo first semester of academic year 2018/2019 with 32 students. Data collection techniques used are tests, observations, and documentation. The stages of data analysis in this study are data collection, data reduction, data presentation, and conclusion. The success indciator is the average score of the student's test at least 80.0 and many students with a value above the minimum mastery criteria of 70,0 reach $\geq 93 \%$. Based on the research that has been done, it can be concluded that the application of cooperative learning model type TPS can improve learning result of civic education of class IX C SMP Negeri 2 Sukoharjo. Before the action / pre cycle, student learning outcomes reaching KKM 18 students or 59,37\%, in cycle I, 25 students or $78,12 \%$ and in cycle II, 30 students or $93,75 \%$. The average value of the class
\end{abstract}


before the action/ pre cycle was 78.12\%after the first cycle action was 77,81 and after the second cycle action was 82,88 .

Keywords: Cooperative learning model type TPS, learning achievementcivic education.

\section{Pendahuluan}

Salah satu pelajaran yang diterapkan dalam pendidikan formal adalah Pendidikan Kewarganegaraan (PKn). PKnadalah mata pelajaran yang selalu ada disemua jenjang pendidikan, mulai dari SD sampai perguruan tinggi, sebagai pelajaran inti. Mengingat pentingnya peranan PKn maka prestasi belajar PKn setiap sekolah perlu mendapat perhatian yang serius. Oleh karena itu para siswa dituntut untuk menguasai pelajaran PKn karena mata pelajaran PKn berpengaruh untuk menunjang keberhasilan belajar siswa untuk menempuh pendidikan yang lebih tinggi. Proses pembelajaran PKn tidak selamanya berjalan efektif karena masih ada beberapa siswa yang mengalami kesulitan dalam belajar PKn. Banyak siswa memandang pelajaran PKn adalah pelajaran yang sulit sehingga kurang dinikmati dan bahkan dihindari oleh sebagian siswa. Hal itu menyebabkan rendahnya prestasi belajar PKn siswa. Rendahnya prestasi belajar PKn siswa disebabkan karena pada umumnya guru menggunakan model pembelajaran konvensional. Model pembelajaran konvensional untuk mata pelajaran $\mathrm{PKn}$ tentu tidak relevan dan akan menimbulkan kesenjangan bagi pemahaman siswa. Dalam pembelajaran menggunakan model konvensional sebenarnya bukan sejauh mana siswa paham dengan materi yang diajarkan tetapi sejauh mana guru bisa menyampaikan materi itu. Sehingga siswa hanya mendengar apa yang diterangkan oleh guru yang akhirnya siswa tidak terbiasa mengemukakan ide-ide atau gagasan yang ada dalam pikirannya. Inilah yang membuat siswa menjadi pasif dan akhirnya malas untuk mengembangkan kemampuan berfikirnya. Hal tersebut dapat mengakibatkan proses belajar yang telah disajikan oleh guru menjadi tidak tuntas dan tidak paham dengan materi tersebut.

Berkaitan dengan hal tersebut, permasalahan yang sama terjadi di SMP Negeri 2 Sukoharjo dimana kegiatan pembelajaran hanya berpusat pada guru sehingga kegiatan belajar mengajar menjadi kurang menarik sehingga kurang diminati siswa. Berdasarkan hasil ulangan PKn materi Menampilkan Partisipasi dalam Pembelaan Negara pada siswa kelas IX CSMP Negeri 2 Sukoharjo, didapatkan 56,25\% siswa yang tuntas melebihi KKM dan rata-rata nilai 74,56. Jumlah siswa kelas IX C sebanyak 32 siswa, KKM PKn di SMP Negeri 2 Sukoharjo adalah 75. Setiap guru tentunya menginginkan pada saat proses belajar mengajar terjadi suatu interaksi antara guru dan siswa maupun antar sesama siswa. Hal ini menunjukkan bahwa dalam proses belajar mengajar dikelas siswa lebih bersemangat. Dengan kondisi tersebut guru akan lebih mudah dalam menyampaikan materi pelajaran karena pada siswa akan merespon dan memahami dengan baik. Prestasi belajar PKn pun dapat mengalami peningkatan. Salah satu model pembelajaran yang dapat digunakan dalam proses pembelajaran adalah model pembelajaran kooperatif tipe Think Pair Share (TPS). Dimana model ini dikembangkan untuk mencapai prestasi belajar yang berupa prestasi 
akademik, toleransi, keragaman dan perkembangan keterampilan sosial. Dengan model ini diharapkan siswa akan lebih aktif dalam bertanya dan dalam penyampaian pendapat, siswa juga diharapkan akan lebih dapat bersosialisasi dengan teman meraka dan dapat mengumpulkan banyak informasi tentang materi pembelajaran yang belum mereka ketahui sebelumnya. Selain itu, model pembelajaran kooperatif tipeTPSini juga memiliki kelebihan karena pembelajaran disusun dalam bentuk kelompok. Sehingga modelini dianggap sebagai model yang dapat meningkatkan prestasi belajar PKn siswa. Namun perlu diadakan penelitian untuk dapat menyimpulkan bahwa modelTPSdapat meningkatkan prestasi belajar siswa terutama dalam pembelajaran PKn.

Menurut pendapat dari beberapa ahli tentang pembelajaran kooperatif tipe TPSsebagai berikut: (1) Dalam Siti F (2009: 10 Februari 2012), model pembelajaran kooperatif tipe TPS merupakan salah satu tipe pembelajaran kooperatif yang dikembangkan oleh Frank Lyman, dkk dari Universitas Maryland pada tahun 1885 sebagai salah satu struktur kegiatan cooperative learning. TPS memberikan waktu kepada para siswa untuk berpikir dan merespon serta saling bantu satu sama lain. TPS memberi siswa kesempatan untuk bekerja sendiri serta bekerja sama dengan orang lain; (2) Pembelajaran kooperatif TPS(Huda, 2011: 136) dalam cooperative lerning metode,teknik, struktur dan model penerapan, memungkinkan siswa untuk bekerja sendiri dan bekerja sama dengan orang lain sehingga bisa mengoptimalkan partisipasi siswa; (3) Pembelajaran kooperatif tipe TPSmerupakan salah satu tipe pembelajaran kooperatif yang merupakan metode pembelajaran dengan membentuk kelompok-kelompok kecil yang juga bertujuan untuk berinteraksi antar siswa, yang mengajarkan kepada siswa bahwa untuk mencapai sesuatu tidak dapat dicapai secara sendiri, melainkan dikerjakan bersama-sama. Mengajarkan kepada siswa untuk dapat berinteraksi dan bergaul dengan siswa yang lain tanpa membedakan ras, suku, dan agama. Pembelajaran kooperatif tipe TPSini membagi siswa menjadi beberapa kelompok yaitu kelompok 1 sampai kelompok 8, yang masing-masing kelompok mengerjakan tugasnya sendiri-sendiri. Siswa diajarkan untuk belajar bersama dengan siswa yang lain, saling bertukar informasi yang mereka miliki, dan mengajarkan sportifitas dalam kegiatan kelompok terebut. Pembelajaran kooperatif tipe TPSini adalah variasi dalam kegiatan kelompok yang sebelumnya pernah ada, dengan penggunaan metode ini diharapkan siswa dapat lebih aktif didalam menerima pembelajaran dan diharapkan siswa tidak bosan dan lebih mudah dalam menerima penjelasan yang diterangkan oleh guru yang membuat peningkatan prestasi belajar siswa terutama pada pembelajaran PKn.

Langkah-langkah kegiatannya adalah sebagai berikut: (1) Guru membagi siswa dibagi dalam beberapa kelompok, setiap kelompok terdiri dari 4 siswa yang masing-masing dalam kelompok memiliki peran yang sama yaitu mengerjakan soal yang diberikan guru; (2) Guru menyiapkan Siswa untuk mempelajari materi pelajaran yang telah diberikan dengan satu kelompoknya dan membantu teman satu kelompok apabila ada yang kurang memahami materi yang dipelajari; (3) Setiap siswa memikirkan jawaban soal masingmasing; (4) Kemudian setiap siswa mendiskusikan jawaban dalam satu kelompok; (5) Setiap kelompok mempresentasikan jawaban didepan kelas yang jawabannya benar akan diberikan tambahan poin oleh guru; (6) Setelah satu babak kemudian soal pertanyaan diputar lagi agar tiap kelompok mendapat soal yang berbeda dari soal sebelumnya, demikian seterusnya. Kemudian diakhir kegiatan guru bersama-sama dengan siswa menyimpulkan dari materi yang telah dipelajari. Alternatif yang dapat ditempuh dalam meningkatkan prestasi belajar siswa adalah melalui kreatifitas guru dalam memilih model 
pembelajaran.Pemilihan model pembelajaran yang tepat dan bervariasi dapat meningkatkan prestasi belajar siswa terutama dalam mata pelajaran PKn. Karena tidak semua model cocok digunakan dalam penyampaian materi, kreativitas guru sangatlah diperlukan dalam pemilihan model pembelajaran yang akan digunakan. Dengan menggunakan model pembelajarana yang tepat dan bervariasi dalam penyampaian materi dapat membantu siswa untuk meningkatkan ide, gagasan dan kreativitas yang dimiliki siswa. Peran guru sebagai fasilitator sangatlah membantu siswa mengembangkan kreativitas yang mereka miliki, siswa juga akan dituntut untuk aktif dalam proses pembelajaran, ini membuat siswa menjadi lebih bersemangat dan bertanggung jawab dalam menemukan hasil jawaban yang diberikan kepada siswa. Pembentukan kelompok juga sangat berguna dalam meningkatkan prestasi belajar siswa terutama pada mata pelajaran PKn, siswa juga akan belajar untuk bersosialisasi dengan teman yang lain, dengan demikian akan menjalin kekompakan dan kerja sama dalam menemukan solusi dari masalah yang diberikan kepada siswa. Pembentukan kelompok akan membuat siswa menjadi senang dalam mengikuti pembelajaran dan tujuan yang didasarkan pada alasan bahwa untuk mencapai sesuatu tidak dapat dicapai secara sendiri, melainkan harus dikerjakan secara bersama-sama, hal ini akan meningkatkan kekompakan, keaktifan, serta kerja sama. Siswa memungkinkan dapat meraih keberhasilan dalam belajar, di samping itu juga akan melatih siswa untuk meningkatkan keterampilan berpikir, dan keterampilan sosial seperti mengemukakan pendapat, menerima saran, bekerja sama dan rasa setia kawanan. Berdasarkan latar belakang di atas, maka dapat dirumuskan masalah, "Apakah dengan menerapkan model pembelajaran kooperatif tipeTPSdapat meningkatkan prestasi belajarmateri Menampilkan Partisipasi dalam Pembelaan Negara pada siswa kelas IXC SMP Negeri 2 Sukoharjo semester 1 tahun pelajaran 2018/2019?”.

\section{Metode Penelitian}

Penelitian ini adalah Penelitian Tindakan Kelas.Penelitian tindakan kelas merupakan suatu pencermatan terhadap kegiatan yang sengaja dimunculkan, dan terjadi dalam sebuah kelas (Arikunto, 2010: 130).Penelitian ini dilaksanakan di SMP Negeri 2 Sukoharjo.Tahap-tahap pelaksanaan kegiatan dilakukan selama kurang lebih enam bulan yaitu sejak bulan Juli sampai dengan November 2018.Peneliti sebagai guru SMP Negeri 2 Sukoharjobertindak sebagai subjek yang melakukan tindakan kelas. Teman sejawat sesama guru mata pelajaran PKn sebagai observer.Kepala Sekolah bertindak sebagai subjek yang membantu dalam perencanaan dan pengumpulan data. Subjek yang menerima tindakan adalah siswa kelas IX CSMP Negeri 2 Sukoharjosemester 1tahun pelajaran 2018/2019 sebanyak 32 siswa. Teknik pengumpulan data yang digunakan adalah: tes, observasi dan dokumentasi. Tes adalah serentetan pertanyaan atau latihan serta alat lain yang digunakan untuk mengukur keterampilan, pengetahuan inteligensi, kemampuan atau bakat yang dimiliki oleh individu dan kelompok (Arikunto, 2010: 183). Tes digunakan adalah jenis tes hasil(achievement test) berupa kuis individu.Tes ini digunakan untuk mengukur pencapaian siswa setelah mempelajari materi. Hal ini dapat juga sebagai alat untuk mengetahui tingkat pemahaman siswa setelah mempelajari materi Menampilkan Partisipasi dalam Pembelaan 
Negara dengan menggunakan model pembelajaran kooperatif tipeTPS.Tes tertulis adalah suatu teknik penilaian yang menunutut jawaban secara tertulis, baik berupa pilihan atau isian. Tes yang jawabannya berupa pilihan meliputi pilihan ganda, benar salah dan menjodohkan, sedangkan tes yang jawabannya berupa isian berbentuk isian singkat atau uraian (Suprijono, 2013:138). Observasi atau pengamatan dilakukan guna memperoleh data yang akurat, dengan menggunakan lembar observasi. Lembar observasi digunakan untuk memonitor dan mengevaluasi setiap tindakan agar kegiatan observasi tidak terlepas dari konteks permasalahan dan tujuan penelitian. Observasi yang digunakan adalah observasi sistematis, yaitu observasi yang dilakukan oleh pengamat dengan menggunakan pedoman sebagai instrumen pengamatan dan observasi non-sistematis yang dilakukan dengan tidak menggunakan instrumen pengamatan.Dokumentasi diperoleh dari hasil kuis siswa, lembar observasi, lembar wawancara, catatan lapangan, daftar siswa, dan foto-foto selama proses kegiatan belajar mengajar. Dokumentasi ini dimaksudkan adalah sebagai bukti-bukti konkret dari penelitian tindakan kelas tersebut.

Instrumen yang digunakan dalam penelitian berupa tes, lembar observasi dan lembar dokumentasi. Tes berbentuk tes tertulis yang dilakukan dalam post test dan kuis individu. Tes ini digunakan untuk mengetahui sejauh mana peningkatan prestasi belajar siswa dengan penerapan model pembelajaran kooperatif tipe TPS. Lembar Observasi, digunakan lembar observasi prestasi belajar siswa dan lembar observasi pelaksanaan pembelajaran kooperatif. Lembar observasi digunakan pada setiap pembelajaran sehingga kegiatan observasi tidak terlepas dari konteks permasalahan dan tujuan penelitian, untuk lembar prestasi belajar siswa digunakan pada saat siswa dapat menyelesaikan permasalahan dengan kegiatan belajar mengajar dan sedangkan lembar observasi pelaksanaan kegiatan belajar mengajar dengan model pembelajaran Kooperatif Tipe TPS digunakan sebagai pedoman peneliti dalam melakukan observasi pelaksanaan kegiatan belajar mengajar dengan menggunakan model pembelajaran kooperatif tipe TPS. Lembar dokumentasi ini bertujuan untuk mengetahui data siswa selama kegiatan penelitian berlangsung.Lembar dokumentasi ini berupa, foto-foto kegiatan pembelajaran, daftar hadir kegiatan pembelajaran, daftar hadir, daftar nilai, dan sebagainya. Indikator keberhasilan kinerja dalam penelitian ini adalah meningkatnya prestasi belajarPKn materi Menampilkan Partisipasi dalam Pembelaan Negara siswa, yang ditunjukkan dengan meningkatnya nilai rata-rata tes siswa sekurang-kurangnya 80,0 dan banyak siswa dengan nilai di atas kriteria ketuntasan minimal (KKM) yaitu $\geq 75,0$ mencapai $\geq 90 \%$.

\section{Hasil Penelitian}

Deskripsi data hasil penelitian yang telah dilakukan di kelas IX CSMP Negeri 2 Sukoharjo adalah sebagai berikut.Berdasarkan observasi awal di kelas IX Cmata pelajaran PKndengan materiMenampilkan Partisipasi dalam Pembelaan Negaradiperoleh data, dari 32 siswa yang mencapai nilai kriteria ketuntasan minimal sebanyak 18 siswa $(56,25 \%)$, dengan nilai rata-rata kelas sebesar 74,56.Penelitian ini dilakukan dengan indikator kinerja nilai rata-rata tes siswa sekurang-kurangnya 80,0 dan banyak siswa dengan nilai di atas kriteria ketuntasan minimal yaitu $\geq 75,0$ mencapai $\geq 90 \%$. Kemudian peneliti merencanakan observasi survai berikutnya untuk mengetahui kebenarannya. Hasil observasi awal menunjukkan bahwa guruyang mendominasi kegiatan pembelajaran dan siswa cenderung tidak aktif.Salah satu solusi yang dikembangkan adalah penggunaan 
model pembelajaran yang baru yaitu dengan Model Pembelajaran Kooperatif Tipe TPS. Dengan penggunaan model pembelajaran tersebut diharapkan akan menciptakan suasana belajar yang berbeda, bervariasi dan menyenangkan sehingga dapat menarikperhatian siswa, meningkatkan keaktifan siswa yang muara akhirnya meningkatkan prestasi belajar siswa. Tindakan kelas siklus I dilaksanakan di SMP Negeri 2 Sukoharjo kelas IXC. Setelah langkah apersepsi dilanjutkan dengan penyampaian materi dengan model pembelajaran kooperatif tipe TPS. Berdasarkan hasil evaluasi pada siklus I menunjukkan adanya peningkatan prestasi belajarsiswa. Prestasi belajar siswa sebanyak 25 mencapai nilai kriteria ketuntasan minimal $78,12 \%$, rata-rata kelas naik menjadi 77,81 . Berdasarkan pengamatan tersebut dapat diketahui bahwa proses pembelajaran pada siklus pertama belum berhasilmaksimaldan belum mencapai indikator kinerja yang diharapkan. Peningkatan hasil, jika dibandingkan hasil prasiklus yang mencapai KKM sebanyak 18 siswa atau 56,25\% setelah diberi tindakan penerapan siklus I, siswa yang mencapai KKM sebanyak 25 siswa atau $78,12 \%$.

Tabel 1. Perkembangan Siswa Mencapai KKM Sebelum Tindakan/Prasiklus ke Siklus I

\begin{tabular}{cccc}
\hline No & Hasil Siswa & Prasiklus & Siklus I \\
\hline & Siswa mencapai KKM & 18 & 25 \\
\hline
\end{tabular}

Dari tabel di atas dapat disimpulkan bahwa prestasi belajarPKn materi Menampilkan Partisipasi dalam Pembelaan Negarasiswa dengan menerapkan model pembelajaran kooperatif tipe TPSpadapelaksanaan tindakan siklus I mengalami peningkatan. Siswa yang mencapai KKM Sebelum dilakukan tindakan atau prasiklus 18 siswa, setelah tindakan siklus I sebanyak 25 siswa sehingga meningkat 7 siswa. Setelah dievaluasi bersama dari pelaksanaan tindakan pada siklus I yang digunakan sebagai bagian pertimbangan perencanaan pembelajaran siklus berikutnya, dengan perencanaan perbaikan untuk mengatasi kekurangan dan kesalahan yang dilakukan pada siklus I. Berdasarkan pembelajaran secara keseluruhan pada tindakan kelas siklus II menunjukan adanya peningkatan yang signifikan.Prestasi belajar siswasebanyak 30 siswa $(93,75 \%)$ mencapai nilai kriteria ketuntasan minimal. Sehingga rata-rata nilai kelas IX C naik menjadi 82,88.

Tabel 2. Perkembangan Siswa yang Mencapai KKM Siklus I ke Siklus II

\begin{tabular}{cccc}
\hline No & Hasil Siswa & Siklus I & Siklus II \\
\hline & Siswa mencapai KKM & 25 & 30 \\
\hline
\end{tabular}

Dari tabel di atas dapat disimpulkan bahwa prestasi belajarMenampilkan Partisipasi dalam Pembelaan Negarasiswa dengan menerapkan model pembelajaran kooperatif tipe TPS, padapelaksanaan tindakan siklus II mengalami peningkatan. Siswa yang mencapai KKM pada saat dilakukan tindakan siklus I sebanyak 25 siswa, setelah tidakan siklus II 
sebanyak 30 siswa sehingga meningkat5 siswa.Berdasarkan hasil tersebut dapat diketahui bahwa proses pembelajaran sampai dengan pada siklus II berjalan dengan baik dan telah memenuhi indikator kinerja yang diharapkan. Pada siklus I dan II dengan penerapan tindakan menggunakan model pembelajaran kooperatiftipe TPS, sehingga siswa lebih antusias dengan perasaan senang dalam mengikuti kegiatan pembelajaran. Nilai rata-rata siswa sejak sebelum diadakan penelitian hingga setelah diadakan penenelitian sampai dengan siklus II, dapat dilihat pada tabel berikut:

Tabel 3.Perkembangan Siswa Mencapai KKM Sebelum Tindakan/Prasiklus,Siklus I dan II

\begin{tabular}{ccccc}
\hline No & Hasil Siswa & Prasiklus & Siklus I & Siklus II \\
\hline & Siswa mencapai KKM & 18 & 25 & 30 \\
\hline
\end{tabular}

Dari tabel di atas dapat disimpulkan bahwa prestasi belajarmateri Menampilkan Partisipasi dalam Pembelaan Negarasiswa dengan menerapkan model pembelajaran kooperatiftipe TPS, di setiap pelaksanaan tindakan, baik siklus I dan siklus II mengalami peningkatan, yaitu: siswa yang mencapai KKM Sebelum dilakukan tindakan atau prasiklus 18 siswa, setelah tidakan siklus I sebanyak 25 siswa dan setelah tindakan siklus II sebanya 30 siswa, sehingga peningkatan kumulatif dari sebelum tindakan/prasiklus sampai dengan siklus II sebesar 12 siswa.

Tabel 4. Perkembangan Persentase Siswa KKM Sebelum Tindakan/Prasiklus, Siklus I dan Siklus II

\begin{tabular}{ccccc}
\hline No & Hasil Siswa & Prasiklus & Siklus I & Siklus II \\
& Persentase Siswa Mencapai KKM & $56,25 \%$ & $78,12 \%$ & $93,75 \%$
\end{tabular}

Dari tabel di atas dapat disimpulkan bahwa prestasi belajarMenampilkan Partisipasi dalam Pembelaan Negarasiswa dengan menerapkan model pembelajaran kooperatif tipe make a match, di setiap pelaksanaan tindakan mengalami peningkatan, yaitu: persentase siswa yang mencapai KKM Sebelum dilakukan tindakan atau prasiklus $56,25 \%$, setelah tidakan siklus I sebanyak 78,12\% dan setelah tindakan siklus II sebanya $93,75 \%$.

Tabel 5. Perkembangan Nilai Rata-rata KelasSebelum Tindakan/Prasiklus, Siklus I dan Siklus II

\begin{tabular}{ccccc}
\hline No & Hasil Siswa & Prasiklus & Siklus I & Siklus II \\
\hline & Nilai rata-rata & 74,56 & 77,81 & 82,88
\end{tabular}

Dari tabel di atas dapat disimpulkan bahwa prestasi belajarmateri Menampilkan Partisipasi dalam Pembelaan Negarasiswa dengan menerapkan model pembelajaran kooperatif tipe TPS, di setiap pelaksanaan tindakan mengalami peningkatan, yaitu: nilai rata-rata kelas sebelum dilakukan tindakan atau prasiklus adalah 74,56 , setelah tidakan siklus I adalah 77,81 dan setelah tindakan siklus II adalah 82,88 sehingga dari kondisi awal 
sebelum tindakan/prasiklus sampai dengan tidakan pada siklus II terjadi peningkatan. Dari uraian di atas dapat disimpulkan bahwa model pembelajaran kooperatif tipe TPS dapat meningkatkan prestasi belajar materi Menampilkan Partisipasi dalam Pembelaan Negarasiswa kelas IXC SMP Negeri 2 Sukoharjosemester 1tahun pelajaran 2018/2019.

\section{Pembahasan}

Hasil penelitian pada kondisi awal pelaksanaan siklus II diperoleh data yang dapat ditabulasikan sebagai berikut:

Tabel 6. Profil Kelas Sebelum dan Sesudah Tindakan Penelitian

\begin{tabular}{lllll}
\hline No & Hasil Siswa & Kondisi Awal & Siklus I & Siklus II \\
\hline 1 & Nilai rata-rata & 74,56 & 77,81 & 82,88 \\
\hline 2 & Siswa yang tuntas KKM & $\begin{array}{l}18 \text { siswa } \\
(56,25 \%)\end{array}$ & $\begin{array}{l}25 \text { siswa } \\
(78,12 \%)\end{array}$ & $\begin{array}{l}30 \text { siswa } \\
(93,75 \%)\end{array}$ \\
\hline
\end{tabular}

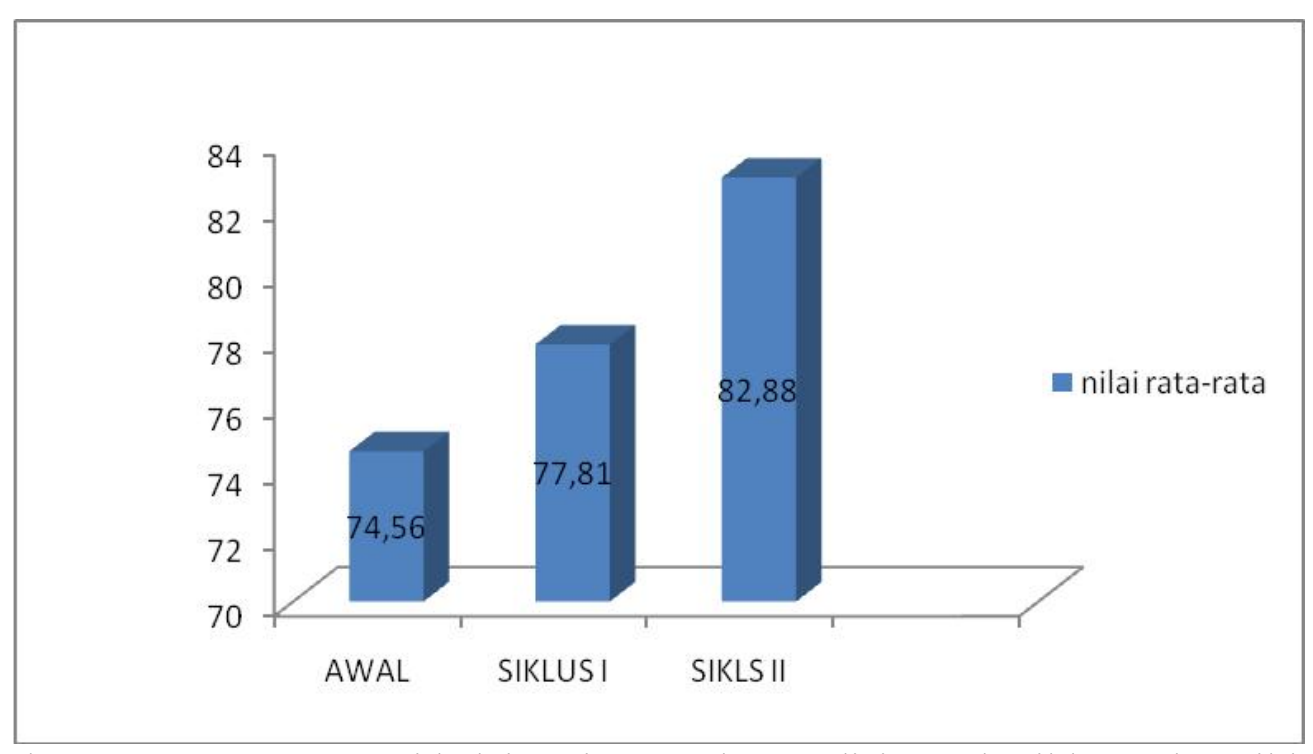

Gambar 1. Rata-rata Prestasi belajar Siswa pada Kondisi Awal, Siklus I, dan Siklus II 


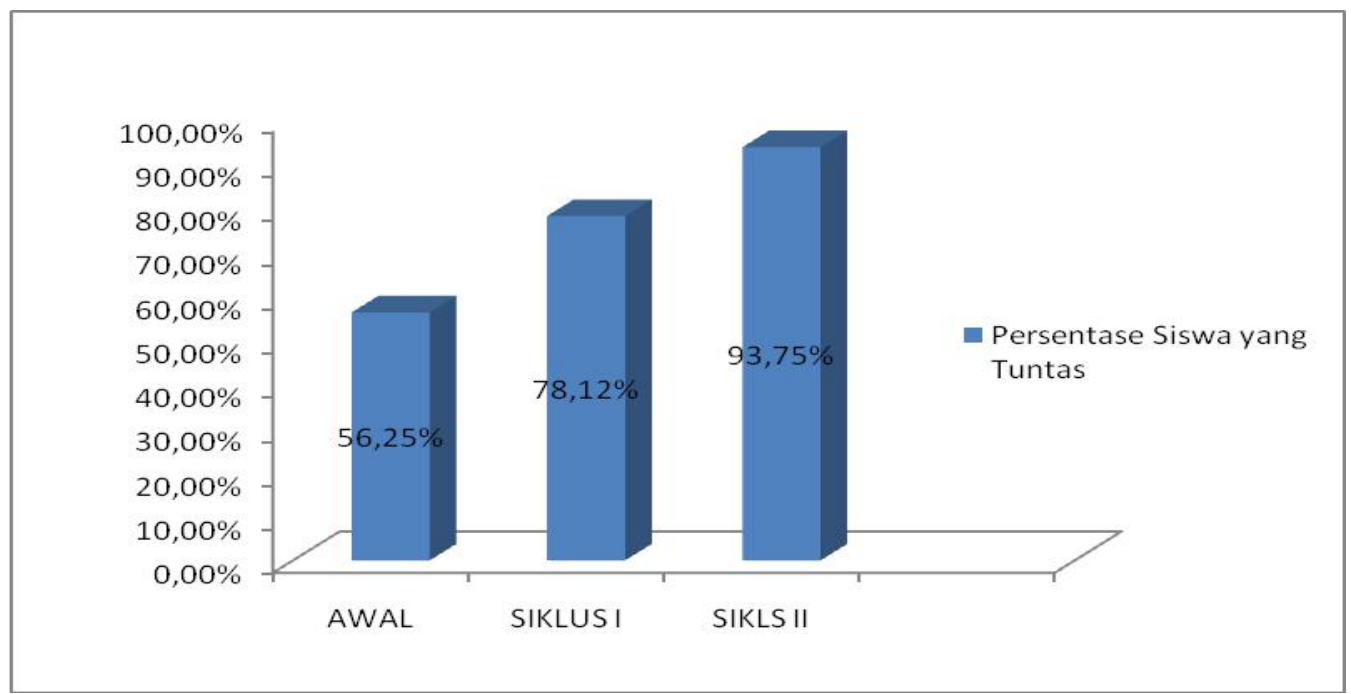

Gambar 2. Persentase Ketuntasan Siswa pada Kondisi Awal, Siklus I, dan Siklus II Berdasarkan grafik di atas dapat ditunjukkan bahwa prestasi belajar siswa dengan menerapkan pembelajaran modelkooperatif tipe TPSdi setiap putaran mengalami peningkatan, yaitu: (1) Sebelum dilakukan tindakan penelitian kelas nilai rata-rata prestasi belajar siswa adalah 74,56 dengan presentase prestasi belajar siswa hanya $56,25 \%$, (2) Setelah dilakukan tindakan pada siklus I nilai rata-rata hasil belajar siswa mengalami peningkatan yaitu 77,81 dengan presentase ketuntasan $78,12 \%$, tetapi belum mencapai indikator yang diharapkan; (3) Pada siklus II nilai rata-ratahasil belajar siswa meningkat yaitu menjadi82,88dengan presentase ketuntasan sebesar 93,75\% dan sudah mencapai indikator yang diharapkan maka penelitian tindakan kelas ini sudah berhasil. Rata-rata prestasi belajarsiswa pada kondisi awal 74,56 dengan persentase ketuntasan belajar siswa sebesar 56,25\%, pada siklus II naik menjadi 82,88 $\geq 80,0$ (indikator kinerja) dengan presentase ketuntasan belajar siswa sebesar 93,75 $\geq 90 \%$ (indikator kinerja). Jadi, indikator kinerja sudah tercapai sehingga tidak dilanjutkan ke siklus berikutnya.

\section{Simpulan dan Saran}

Berdasarkan hasil penelitian dapat disimpulkan, dengan penerapan model pembelajaran kooperatif tipe TPSdapat meningkatkan prestasi belajarmateri Menampilkan Partisipasi dalam Pembelaan Negarasiswa kelas IX CSMP Negeri 2 Sukoharjosemester 1tahun pelajaran2018/2019. Penelitian Tindakan Kelas yang dilaksanakan di SMP Negeri 2 Sukoharjo ini sudah berjalan dengan cukup baik dan hasil yang baik pula. Namun masih banyak hal yang perlu diperbaiki. Oleh karena itu, peneliti memberikan beberapa saran. (1) Siswa diharapkan dapat lebih meningkatkan kemampuan diri melalui peran aktifnya dalam mengikuti kegiatan belajar mengajar. Peran aktif tersebut meliputi peran aktif dalam bertanya, mengemukakan pendapat maupun mempresentasikan gagasannya. (2) GuruPKn hendaknya dapat menumbuh kembangkan kreativitas dalam menjalankan profesinya sebagai fasilitator dan motivator dalam menyampaikan pembelajaran secara kreaktif dan inovatif pada siswa dalam penyampaian materi, sehingga siswa dapat menerima dan memahami materi yangdiajarkan dengan baik. (3) Penelitian Tindakan Kelas ini diharapkan 
akan membawa dampak positif terhadap perkembangan sekolah yang nampak pada peningkatan prestasi belajar siswa sehingga dapat meningkatkan prestasi dan kualitas sekolah.

\section{Daftar Rujukan}

Arikunto, Suharsimi. (2010). ProsedurPenelitian. Jakarta: RinekaCipta.

----------------. (2006). Prosedur Penelitian Suatu Pendekatan Praktik. Jakarta: Rineka Cipta.

Aunurrahman. (2009). Belajar dan Pembelajaran, Bandung : Alfabeta.

Dimyati dan Mudjiono. (2009). Belajar dan Pembelajaran. Jakarta: Rineka Cipta.

Hamalik, Oemar. (2004). Proses Belajar Mengajar. Jakarta: Bumi Aksara.

Isjoni. (2007). Cooperative Learning Efektifitas Pembelajaran Kelompok. Bandung: Alfabeta.

Poerwodarminto. (2003). Kamus Umum Bahasa Indonesia. Jakarta: Balai Pustaka.

Suprijono, Agus. (2009). Cooperative Learning Teori dan Aplikasi Paikem. Yogyakarta: Pustaka Pelajar. 